\title{
EFFECT OF ANTHELMINTIC TREATMENT ON THE REPRODUCTIVE PERFORMANCE OF ANESTROUS CROSSBRED COWS
}

\author{
El-Kon, I.I. and M.A. Harfoosh* \\ Depart. of Theriogenology, Faculty of Veterinary Medicine, Kafrelsheikh University \\ * Animal Health Research Institute, Kafrelsheikh
}

\begin{abstract}
Thirty-five multiparous anestrous cows were infested with Trematode parasites used to determine the effect of anthelmintic treatment on the reproductive performance and some blood constituents. The reproductive status of all animals and the changes in the ovarian activities were assessed by rectal examination. Faecal samples were collected from all animals directly after rectal examination. All animals were observed for estrus signs and those came in estrous were mated. Serum progesterone concentration was measured to determine ovarian activity prior to treatment and to confirm the occurrence of ovulation as well as to determine early pregnancies which were confirmed by rectal examination at 45 days post service. Serum samples were collected for determination of total proteins, calcium, inorganic phosphorous, estradiol and insulin like growth factor-I (IGF-I). The results of the present study indicated that, the most common parasitic infection in case of anestrum were fasciolia and paramphistoma. Anthelminitic treatment significantly $(P<0.001)$ increase the serum levels of calcium, inorganic phosphorus, estradiol, progesterone and IGFI. Anthelmintic treatment improves the reproductive performance of anestrous cows infested with Trematode parasites as indicated by higher oestrous response, higher (73.5\%) first service and overall (83.33\%) conception rates.
\end{abstract}




\section{INTRODUCTION}

Infertility problems in dairy herds not only are attributed to managemental or infectious causes, but also are associated with the presence of parasitism (Mage et al., 1989). The negative impact of a parasitic infection not only affects the weight gain of the replacement heifer, but also the reproductive performance and hence the productivity of a cow-calf herd (Ilchmann and Schillineger, 1997). The presence of subclinical parasitic burden will affect nutrient utilization and possibly alter animal metabolism (EI-Sasser et al., 1991). Moreover, El-Sasser et al. (1988) reported that the plane of nutrition and parasite status affect weight gain and blood concentrations of growth hormone (GH), insulin, thyroxine, triiodothyronine and IGF-I. Growth hormone, insulin and IGF-I are linked with the intermediate metabolism and reproduction (Steiner et al., 1983). The antiparasite treatment of cows was associated with reduced number of days to conception, increased conception rate at first service and higher pregnancy rate (Orellana et al., 1999; Loyacano et al., 2002). In addition serum concentration of progesterone $\left(\mathrm{P}_{4}\right)$ was significantly lower in heifer infected with fascioliasis whereas, fascioliasis alter the serum concentrations of E2 which in turn results in an abnormally low concentration of $\mathrm{P}_{4}$, probably due to under developed or absent Corpora lutea (Lopez-Diaz et al., 1998). Abnormal prolongation of the anestrous post partum period, increase number of service per conception and the open days period, as well as decrease in conception rate have been noticed in case of parasitism (Barakat and Selim, 1995; Walsh et al., 1995). Therefore, the present study was under taken to find out (1) The most predominant parasite in case of anestrum cows. (2) Treatment of the parasitic infection using the suitable anthelimintic drug. and (3) Identify the rate of improvement in the reproductive efficiency of cows after anthelmintic treatment (Oestrus response, conception rate and pregnancy rate).

Kafrelsheikh Vet. Med. J. Vol. 4 No. 2 (2006) 


\section{MATERIALS AND METHODS}

\section{Animals:}

A total of 35 anestrum crossbred cows (4-8 years), belonging to Mandura veterinary Unit (Kafr El-Sheikh), having normal parturition were used in this study. They were fed on Tibn and hay in dry season and barseem and Tibn with concentrates during green season. According to the veterinary authority regulations, all animals in the area of investigation were given regular vaccination against the common infectious and contagious diseases and circular treatment against external parasities.

\section{Rectal examination:}

Regarding to the breeding history, a total number of 50 crossbred cows (post-partum anestrum since 4-5 months) were examined per rectum for detection of ovarian activities. All examined animals were suffered from ovarian inactivity. Out of 50 examined crossbred cows, 35 animals were infested with Trematode parasites used in the present study. After treatment all animals were kept under observation and were examined rectaly every week for assessing any change in the ovarian activity. Ovaries seemed to be active when they revealed follicles or Corpora lutea on their surfaces. Moreover, the cows were observed for oestrus signs. The day at which the female stand to be mounted was considered the day of estrus. All cows were naturally served using fertile bulls. Based on oestrus detection or mating the following reproductive performances were recorded:

a. Time elapsed from treatment to onset of heat and rate of heat response.

b. First service and overall conception rates.

c. Pregnancy diagnosis after 45 days from the service. 


\section{Parasitological examination:}

Faecal samples were collected from all animals directly after rectal examination as well as 14 days post-treatment. All samples were examined by both sedimentation and flotation techniques for detection of parasitic eggs according to Sulsby (1988). Egg counts were determined according to Jordan and Whitelock (1939).

\section{Treatment regime:}

According to the parasitological examination, the infected animals were treated using vasinex (Novartis Animal Health Inc. Co.) given as a single dose (10 mg/kg body weight) in case of fasciala infection. Animals infected with paramphistomum were treated using Zanil (Schering Plough Veterinaire Company) as a single dose (10 mg/kg body weight).

\section{Blood sampling schedules:}

Blood samples were collected from all animals by Jugular venepuncture immediately before and every week after treatment till the time of heat, every week post service till $24^{\text {th }}$ day form the last service. Blood was drawn into clean vials, left to clot at room temperature for one hour and centrifugated at 3000 rpm for about 15 minutes. The obtained serum was stored frozen at $-20^{\circ} \mathrm{C}$ until the chemical and hormonal analyses.

\section{Chemical analysis:}

a. Determination of serum total proteins: serum total proteins (gm \%) were determined according to Josephson and Gyllensard (1975).

b. Determination of serum inorganic phosphorus: serum inorganic phosphorus (mg \%) was determined according to Tietz (1986).

c. Determination of serum calcium: serum calcium (mg \%) was determined by the method described by Gitelman (1967). 


\section{Analysis of hormones and IGF-I:}

a. Determination of serum progesterone concentration: Serum progesterone concentration was measured by using direct quantitative measurement of progesterone in serum progesterone coated tube using radio immuno assay technique according to Abraham (1981).

b. Determination of serum estradiol concentration:( $\left.E_{2}\right)$ concentration was measured by Radioimmuno assay (RIA) as described by Lichtenberg et al. (1992).

c. Determination of serum insulin like growth factor I: serum IGF-I concentration was determined by Non-extraction IFG-IELISA DSL10-2800 according to Daughaday and Rotwein (1989).

\section{Statistical analysis:}

The obtained data were computed using a computerized statistical analysis system (SAS, 2000) and expressed as mean \pm SEM. The student " $t$ " test was used to determine the effect of treatment. All statistical methods were carried out according to Snedecor and Cochran (1980).

\section{RESULTS}

\section{Incidence of parasitic infestation in case of ovarian inactivity in} cows:

Table 1 revealed that about $11.42 \%$ of the examined cows were infected with fasciola parasite while the remaining (88.90\%) were infected with paramphistomum. However, all animals infected with fasciola were mixed with paramphistomum parasites.

Table (1): Incidence of helminth parasites infection in examined cows:

\begin{tabular}{|c||c|c||c|c||c|c||}
\hline \multirow{2}{*}{$\begin{array}{c}\text { Number of } \\
\text { examined animals }\end{array}$} & \multicolumn{2}{|c||}{ Infected animals } & \multicolumn{2}{|c|}{ Fasciola } & \multicolumn{2}{|c|}{ Paramphistomum } \\
\cline { 2 - 7 } & No. & $\mathbf{( \% )}$ & No. & $\mathbf{( \% )}$ & No. & $\mathbf{( \% )}$ \\
\hline \hline 50 anestrous crossbred cows & 35 & 70 & 4 & 11.42 & 31 & 88.58 \\
\hline
\end{tabular}

Kafrelsheikh Vet. Med. J. Vol. 4 No. 2 (2006) 
The average egg count in the examined cows (pretreatment) were 100-300 eggs/gm and 300-800 eggs/gm for Fasciola and paramphistomum parasites, respectively, whereas, the average egg count in treated animals was zero (Table, 2).

Table (2): Effect of some anthemintics on trematode parasite;

\begin{tabular}{|c|c|c|c|c|}
\hline $\begin{array}{l}\text { Number of } \\
\text { treated cows }\end{array}$ & Parasite & Drug used & $\begin{array}{l}\text { Average count } \\
\text { (eggs/gm) } \\
\text { pretreatment }\end{array}$ & $\begin{array}{l}\text { Average count } \\
\text { (eggs/gm) } \\
\text { posttreatment }\end{array}$ \\
\hline \multirow{2}{*}{35} & Fasciola & Vasinex & $100-300$ & Zero \\
\hline & Paramphistomum & Zanil & $300-800$ & Zero \\
\hline
\end{tabular}

\section{II.Effect of anthelmintic drugs on estrus response and conception} rate in anestrous cows:

As shown in Table (3), the percentage of animals detected in estrus after treatment was $85.71 \%$ (30/35). The time from treatment till estrus detection was $45.82 \pm 5.6$ days. The first service conception rate of treated cows was detected by progesterone profile and confirmed by rectal examination at 45 days of pregnancy. The first service conception rate of treated cows averaged $73.50 \%$ whereas, the overall conception rate averaged $83.33 \%$.

Table (3): Reproductive performances of anthelmintic treated cows.

\begin{tabular}{|c|c|c|c|c|c|c|}
\hline & \multicolumn{3}{|c|}{ Heat response } & \multirow{2}{*}{$\begin{array}{c}\text { Treatment } \\
\text { heat interval }\end{array}$} & \multirow{2}{*}{$\begin{array}{c}\text { First service } \\
\text { conception (\%) }\end{array}$} & \multirow{2}{*}{$\begin{array}{c}\text { Overall conception } \\
\text { rate (\%) }\end{array}$} \\
\hline & Total & Resp. & (\%) & & & \\
\hline $\begin{array}{c}\text { Treated } \\
\text { cows }\end{array}$ & 35 & 30 & 85.71 & $\begin{array}{c}45.82 \pm 5.6 \\
\text { (days) }\end{array}$ & $\begin{array}{l}73.50 \\
22 / 30\end{array}$ & $\begin{array}{l}83.33 \\
25 / 30\end{array}$ \\
\hline
\end{tabular}

\section{Chemical analysis of serum:}

\section{A. Total proteins:}

The serum total proteins(gm/dl)concentration was slightly increased from 6.42 to 6.68 due to anthelmintic treatment. Such variation doesn't reach the level of statistical significant (Table, 4). 
Effect Of Anthelmintic Treatment On The Reproductive ...

Table (4): Serum total protein concentration $(\mathrm{gm} / \mathrm{dl})$ in anthelmintic treated cows (means + SEM).

\begin{tabular}{|c||c|c||c|}
\hline Group & Before treatment & After treatment & t-value \\
\hline \hline Total proteins $(\mathrm{gm} / \mathrm{dl})$ & $6.42 \pm 0.13$ & $6.68 \pm 0.05$ & $1.85^{\mathrm{NS}}$ \\
\hline
\end{tabular}

NS: Non significant.

\section{B. Calcium and phosphorus:}

The results given in Table (5) revealed that the differences in the serum calcium and inorganic phosphorus concentrations (mg/dl) due to anthelmintic treatment were highly $(\mathrm{P}<0.0001)$ significant with the higher values recorded after treatment of anestrous cows.

Table (5): Serum calcium and inorganic phosphorus concentrations (mg/dl) in anthelmintic treated cows.

\begin{tabular}{|l|c||c||c|}
\hline \multicolumn{1}{|c|}{ Group } & Before treatment & After treatment & t-value \\
\hline \hline Calcium (mg/dl) & $7.71 \pm 0.24$ & $9.77 \pm 0.010$ & $7.70^{* *}$ \\
\cline { 2 - 4 } Inorganic phosphorus (mg/dl) & $3.40 \pm 0.17$ & $5.13 \pm 10$ & $10.15^{* *}$ \\
\hline
\end{tabular}

**: $\mathbf{P}<0.0001$

\section{Effect of anthelmintic treatment on serum estradiol $(\mathrm{Pg} / \mathrm{ml})$ and insulin like growth factor I (ng/ml) concentrations:}

A highly significant increase $(\mathrm{P}<0.0001)$ was recorded in the serum concentrations of estradiol and insulin like growth factor I as a result of anthelmintic treatment (Table 6).

Table (6): Serum concentrations of oestrogen and insulin like growth factor I (IGFI) in anthelmintic treated cows (means \pm SEM).

\begin{tabular}{|c||c||c|c||}
\hline Group & Before treatment & After treatment & t-value \\
\hline \hline Oestrogen (pg/ml) & 41.09 & 62.81 & $4.99^{* *}$ \\
& \pm 1.085 & \pm 3.44 & \\
\cline { 2 - 4 } & 62.60 & 139.00 & $7.01^{* *}$ \\
Insulin like growth factor-I (ng/ml) & \pm 9.03 & \pm 11.57 & \\
\hline
\end{tabular}

**: $\mathbf{P}<0.0001$

$\overline{\text { Kafrelsheikh Vet. Med. J. Vol. } 4 \text { No. } 2 \text { (2006) }}$ 


\section{Effect of anthelmintic treatment on serum progesterone $(\mathrm{ng} / \mathrm{ml})$ concentration:}

The mean serum progesterone concentration $(\mathrm{ng} / \mathrm{ml})$ of examined cows is presented in Table 7. Average values of $0.32 \pm 0.02$ and $1.76 \pm$ $0.38 \mathrm{ng} / \mathrm{ml}$ were recorded in cows with anestrum and cows resuming ovarian activity, respectively. The serum progesterone concentration was $2.68 \mathrm{ng} / \mathrm{ml}$ in pregnant cows (Table 7).

Table (7): Serum progesterone concentration $(\mathrm{ng} / \mathrm{ml})$ in anthelmintic treated cows (means \pm SEM).

\begin{tabular}{|c||c||c|}
\hline & Progesterone concentration $\mathbf{( n g} / \mathbf{m l})$ & t-value \\
\hline \hline Before treatment & $0.32 \pm 0.02$ & $6.47^{* *}$ \\
\cline { 2 - 3 } After treatment & $1.76 \pm 0.38$ & \\
\hline 24 days post mating & $2.68 \pm 0.38$ & \\
\hline
\end{tabular}

**: $\mathbf{P}<0.0001$

\section{DISCUSSION}

The present results revealed that there was improvement in the ovarian activity of cows suffering from prolonged anestrum due to anthelmintic treatment as noticed by the higher (85.71\%) response to heat and the time elapsed from the treatment to heat. In addition, anthelmintic treatment of anestrous cows resulted in higher (73.5\%) first service and overall (83.33\%) conception rates. Improvement of the reproductive performance of anoestrous cows following administration of anthelmintic has been attributed to their action on the vital processes which improve the general health condition of the animal (Holste et al., 1986; Nowosad et al., 1988; Barakat and Selim, 1995) Moreover, the presence of parasite will affect nutrient utilization and possibly alter animal metabolism and (or) increased levels of cytokins such as tumour necrosis factor (El-Sasser et al., 1991). Additionally, increased peripheral levels of cytokins in rats increases protein catabolism and Kafrelsheikh Vet. Med. J. Vol. 4 No. 2 (2006) 
increase glucose turnover (Meszaros and Taylor, 1989). The present findings are in agreement with the results of El-Desouky (1997) who reported that, anthelmintic administration to anestrous cows improves the reproductive performance of the cows as indicated by oestrous response, lower service per conception and higher conception rate. In addition the present findings are explained by Arneberg (1996) who stated that the gastrointestinal tract infection with parasites is associated with inappetence and increased loss of proteins into gastrointestinal tract resulted in changes in host metabolism account for poor productivity in infected animals. In addition to changes in body weight, alterations in body composition also occur such as, higher water percentage and the deposition of fat, protein and skeletal calcium and phosphorous is lower than in free animals (Holmes, 1985). Loyacano et al. (2002) reported that heifers treated for gastrointestinal nematode and liver fluke had higher pregnancy rates than control heifers.

The changes in the chemical constitutions of serum of cows with parasitic infection has been anticipated, a finding which might be useful in prognosing the most efficient treatment resulting in the best reproductive performances. The results of the current study revealed a non significant increase in total proteins after the treatment by anthelmintic when compared before treatment in the same animals. These findings are in agreement with that reported by Abdel-Aziz (1993) who did not find any significant change in the serum total proteins in relation to the ovarian follicular activity. The lower concentration of total proteins in infected cows in relation to treated ones may be attributed to the increased peripheral levels of cytokins which increase protein catabolism (Meszaros and Taylor, 1989). 
The results of the present study reported that, the serum calcium concentration (mg\%) was significantly $(\mathrm{P}<0.0001)$ higher in cows after treatment by anthelmintic compared to before treatment. This finding agreed with that reported in cows (Barakat and Selim, 1995 and ElDesouky, 1997). Moreover, Gupta (1977) reported low calcium levels in anoestrus buffaloes as compared to normally cycling buffaloes.

The results of the current study revealed a highly significant increase in the inorganic phosphors concentration in treated cows compared to before treatment. These results are inagreement with the results of Barakat and Selim, 1995; Selim, 1996 and El-Desouky 1997 who reported that anthelmintic treatment leads to higher inorganic phosphorus concentration. The increased concentration of calcium and inorganic phosphorus after treatment might be attributed to the anthelmintic efficacy against the gastrointestinal parasites in cows (EISawalhy and Hassan, 1996). The link between phosphorus and reproduction can be traced to some early field studies (Theiler et al., 1928) that reported improved reproductive performance when cattle supplemented with phosphorus in the ration. However, there was no specific mechanism of action established to explain the role of phosphorus in reproduction, lowered conception rates and anestrum have been reported with phosphorus deficiency (Tallam et al., 2005). The present finding agreed with the finding of Radheshyan (1982) who found that, lower levels of inorganic phosphorus in serum of anoestrus cows than cycling cows.

Concerning the effect of anthelmintic treatment on the serum concentrations of oestrogen (E2) and insulin like growth factor-I (IGF-I) the present results reported highly significant increase in the levels of E2 and IGF-I after treatment. The serum progesterone concentration was significantly increased in anthelmintic treated cows. The present results are in accordance with the findings of Lopez-Diaz et al. (1998) who 
found that the alterations in steroid hormones metabolism in animals infected with parasites, impair the reproductive performance. The present results indicated that the anthelmilic treatment increased IGF-I which has been shown to be diminished in under fed humans (Thissen et al., 1994), rodents (Gruaz et al., 1994) and ruminants (Schoppee et al., 1996; Yelich et al., 1996). Parasitism diminishes voluntary food intake, impairs protein absorption and increases endogenous protein loss. All these features of parasitism may lead to sever malnourishment which in turn decreased IGFI in infected animals (Lacau- Mengido et al., 2000). Moreover, El-Sasser et al. (1990) found that parasitism decreased feed intake and lowered IGF-I level in calves. The present findings revealed that there was existing relationship between the serum levels of estradiol $\left(\mathrm{E}_{2}\right)$, progesterone $\left(\mathrm{P}_{4}\right)$ and Insulin like growth factor I (IGF-I) as indicated by the higher levels due to anthelmintic treatment. Our results are supported by the results of Zulu et al. (2002) who found that there was relationship between serum IGF-I and estradiol in normal and inactive ovaries cows with higher levels in normal cows and Echternkamp et al. (1994) who reported that IGF-I increased with increase estradiol in cows. Moreover, Spicer et al. (2004) stated that IGF-I and IGF-II play a significant role in thecal cell steroidogenesis during follicular development in cultured bovine thecal cells and play a role in the development of early antral follicles (Walters et al., 2006). The improved fertility of the cows reported herein may be attributed to the improvement of metabolic status of the animals and increased serum levels of IGF-1 whereas, the IGF system may regulate hypothalamic pituitary function and the hypophyseal IGF system may be regulated by the ovarian and hypothalamic hormones thus, circulating and/or locally produced IGF system components may provide a mechanism by which changes in metabolic status of the animals may be perceived at the hypothalamic pituitary-Ovarian axis to regulate reproductive function (Roberts et al., 1997). 
It could be concluded that, parasitic infection is considered one of the most important predominant causes of anestrum in cows. Anthelmintic treatment is very important as a first step in treatment of anestrum because it improves the general health condition of the animals and serum blood constituents as indicated by significant increase in total proteins, calcium, inorganic phosphorus and reproductive hormones which reflected on the ovarian function. Moreover, anthelmintic treatment of anestrous cows increased serum IGF-I which might be involved in resuming ovarian activity.

\section{REFERENCES}

- Abdel-Aziz, M.Z. (1993): Clinico-pathological studies on the postpartum period in buffaloes. M.V.Sc. Thesis, Fac. Vet. Med. Zagazig Univ.

- Abraham, G.E. (1981): The application and natural steroid radioimmunoassay to gynaecologi endocrinology. Radio Assay System in Clinical Endocrinology. Ed. Basel: Marcel Dekker, 475.

- Arneberg, P.; Folstad, I. and Karter, A.J. (1996): Gastrointestinal nematodes depress food intake in naturally infected reindeer. Parsitol., 112: 213-219.

- Barakat, T.M. and Selim, A.M. (1995): The relation between gastro-intestinal nematodes infestation and postpartum ovarian inactivity in buffalo-cows. Zagazig Vet. J. Vol. 23, No. (1): 3538.

- Daughaday, E. and Rotwein, P. (1989): Insulin like growth factor 1 and 11.peptide, messenger ribonucleic acid and gene structures, serum and tissue concentrations. Endocrin. Rev.(10):68-91.

- Echternkamp, S.E.; Howard, H.J.; Roberts, A.J.; Grizzle, J. and Wise, T. (1994): Relationships among concentrations of 
steroids, insulin-like growth factor-1, and insulin-like growth factor binding proteins in ovarian follicular fluid of beef cattle. Biol. Reprod., 51: 971-981.

- Echternkamp, S.E.; Spicer, L.J.; Gregor, K.E.; Canning, S.F. and Hammoud, J.M. (1990): Concentrations of insulin-like growth factor-I in blood and ovarian follicular fluid of cattle selected for twins. Biol. Reprod., 43: 8-14.

- El-Desouky, A.M.M. (1997): Effect of anthelmintic drugs on the reproduction in cows. Ph.D. Thesis, Fac. Vet. Med. Zagazig Univ.

- El-Sasser, T.H.; Caperna; T.J. and Fayer (1991): Tumour necrosis factor-alpha affects secretion of growth hormone secretion by direct pituitary interaction. Proc. Soc. Exp. Biol. Med. 198: 547-552.

- El-Sasser, T.H.; Fayer, R.; Rumsey, T.S. and Hammoud, A.C. (1990): Plasma and tissue concentration and molecular forms of sometostatin in calves infected with sarcocystis cruzi. Domest. Anim. Endocrinol., 7: 537-550.

- El-Sasser, T.H.; Rumsey, T.S. and Hammoud, A.C. (1988): Influence of parasitism on plasma concentrations of growth hormone, somatomedin- $\mathrm{C}$ and somatomedin binding Proteins in calves. J. Endocrinol., 116: 191-198.

- El-Sawalhy, A.A. and Hassan, H.Y. (1996): Anthelmintic efficacy and immuno-biochemical studies of levamisole, ivermectin and thiabendazole against gastrointestinal nematodes. $7^{\text {th }}$ Sci. Cong. 17-19 Nov. 1996, Fac. Vet. Med., Assiut, Egypt.

- Gitelman, H.J. (1967): Quantitative colorimetric determination of calcium in serum. Anal. Biochem., 18: 521.

- Gruaz, N.M.; Arsenijevic, Y.; Wehrenberg, W.B.; Sizonenko, P.C. and Aubert, M.L. (1994): Growth hormone (GH) deprivation induced by passive immunization against rat GHKafrelsheikh Vet. Med. J. Vol. 4 No. 2 (2006) 
releasing factor does not disturb the course of sexual maturation and fertility in the female rate. Endocrinol., 135: 509-519.

- Gupta, S.K. (1977): Anestrus in buffaloes. $1^{\text {st }}$ All India Symp. on Anim. Rep. P.A.U. Ludhiana.

- Holmes, P.H. (1985): Pathogenesis of trichostrongylosis. Vet. Parasitol., 18: 89-101.

- Holste, J.E.; Wallace, D.H.; Hudson, D.B.; Benz, G.W. and Ericsson, G.F. (1986): Reproductive performance of beef cows treated with ivermectin before calving. Modern-VeterinaryPractice, 67(5): 462-464.

- Ilchmann, G. and Schillineger, D. (1997): Parasitic infections and herd fertility. An overview. Tierarctl Prax., 25(2): 130-132.

- Jordan, H. and Whitelock, H. (1939): A new technique for counting nematode eggs in sheep faeces. J. Counc. Sci., Ind. Aust., 12: 50-52.

- Josephson, B. and Gyllensard, A. (1975): Colorimetric determination of total protein in serum. Scan. J. Clin. Lab. Invet., 9: 29.

- Lacau-Mengido, I.M.; Mejia, M.E.; Diaz-Torga, G.S.; Gonzalez Iglesias, A.; Formia, N.; Liberturn, C. and BecuVillalobos, D. (2000): Endocrine studies in ivermectin-treated heifers from birth to puberty. J. Anim. Sci., 78: 817-824.

- Lichtenberg, V.; Schulte-Baukloh, A.; Linder, Ch. and Braendlew (1992): Discrepancies between results and serum 17B-Oestradiol $\mathrm{E}_{2}$ determinations carried out using different immunoassay kits. Lab. Med. 16: 412-416.

- Lopez-Diaz, M.C.; Carro, M.C.; Cadorniga, C.; Diez-Banos, P. and Mezo, N. (1998): Puberty and serum concentrations of ovarian steroids during prepuberal period in Friesian heifers 
artificially infected with fasciola hepatica. Theriogenology, 50: 587-593.

- Loyacano, A.F.; Williams, J.C.; Gurie, J. and DeRosa, A.A. (2002): Effect of gastrointestinal nematode and liver fluke infections on weight gain and reproductive performance of beef heifers. Vet. Parasitol., 107(3): 227-234.

- Mage, C.; Loisel, J. and Bonnand, P. (1989): Fasciola hepatica infection and fertility problems in dairy herds-Revuede-Mecine-Veterinaire, 140: 10, 929-931.

- Meszaros, K.G. and Taylor, J.R.F. (1989): Review article: Ostertagiasis in cattle. J. Vet. Diagn. Invest. 1: 195-204.

- Nowosad, B.; Fudalewiez, W. and Shalsk (1988): Gastrointestinal nematodes of heifers on an industrial farm. Wiadomosci-Parazytologic Zne, 34(3): 2749-293.

- Orellana, P.; Recabarren, S.; Lobos, A.; Islas, A.; Briones, M. and Rublar, L. (1999): Effects of winter supplementation and antiparasite treatment on the reproductive performance of milk herd in the central-south region of Chile. Prev. Vet Med. 38(2-3): 207-215.

- Radheshyan, P. (1982): Studies on causes, incidence and remedial measures of anoestrus cows. M.V.Sc. Thesis, J.N.K.V.V. Jabalpur.

- Roberts, A.J.; Nugent, R.A.; Klindt, J. and Jenkins, T.G. (1997): Circulating insulin-like growth factor-I, insulin-like growth factor binding proteins, growth hormone and resumption of estrus in postpartum cows subjected to dietary energy restriction. J. Anim. Sci., 75: 1909-1917.

- SAS (2000): SAS User's Guide, SAS Institute, Cary, New York, USA.

- Schopee, P.D.; Armstrong, J.D.; Harvery, R.W.; Whitacre, M.D.; Felix, A. and Campbedll, R.M. (1996): Immunization against growth hormone releasing factor or chronic feed 
restriction initiated at 3.5 months of age reduces ovarian response to pulsatile administration of gonadotropin-releasing hormone at 6 months of age and delays onset of puberty in heifers, Biol. Reprod. 55: 87-98.

- Selim, A.M.A. (1996): Nematodiasis of buffaloes and cattle epidemiological studies and efficacy of ivermectin, Moxidectin and albendazole, $7^{\text {th }}$ Sci., Conf. Fac. Vet. Med. Assiut Univ.

- Snedecor, G.W. and Cochran, W.G. (1980): Statistical methods. $7^{\text {th }}$ ed. Ames, Iowa State University Press.

- Spicer, L.J.; Voge, J.L. and Allen, D.T. (2004): Insulin-like growth factor-II stimulates steroidogenesis in cultured bovine thecal cells. Mol. Cell Endocrinol., 227(1-2): 1-7.

- Steiner, R.A.; Cameron, J.L.; McNeil, T.H.; Clifton, D.K. and Bremmer, W.J. (1983): Metabolic signals for the onset of puberty. In. R.L. Norman (Ed.) Neuroendocrine Aspects of reproduction. p: 183. Academic Press, New York.

- Sulsby, E.J. (1988): Helminthes, Arthropodes and protozoa of domesticated animals. Baillierl, Tindol, London.

- Tallam, S.K.; Ealy, A.D.; Bryan, K.A. and Wu, Z. (2005): Ovarian activity and reproductive performance of dairy cows fed different amounts of phosphorus J. Dairy Sci., 88: 36093618.

- Theiler, A.; Green, H.H and Dutoit, P.J. (1928): Studies in mineral metabolism. III. Breeding of cattle on phosphorous deficient pasture. J. Agric. Sci., 18: 369-371.

- Thissen, J.; Ketelslegers, J. and Underwood, L.E. (1994): Nutritional regulation of the insulin. Like growth factor. Endocrinol. Rev., 15: 80-101.

- Tietz, N.W. (1986): Textbook of clinical chemistry. W.B. Saunders. Co., London, Philadelphia, 1841. 
- Walsh, T.A.; Younis, P.J. and Morton, J.M. (1995): The effect of ivermectin treatment of late pregnant dairy cows in south-West Victoria on subsequent milk production and reproductive performance-Aust. Vet. J., 72(6): 201-207.

- Walters, K.A.; Binnie, J.P.; Campbell, B.K.; Armstrong, DG. and Telfer, E.E. (2006): The effects of IGF-I on bovine follicle development and IGFBP-2 Expression are dose and stage dependent. Reproduction, 131(3): 515-523.

- Yelich, J.V.; Wetteman, R.P; Marston, T.T. and Spicer, L.J. (1996): Luteinizaing hormone, growth hormone, insulin-like growth factor-I, insulin and metabolites before puberty in heifers fed to gain at two rates. Domest. Anim. Endocrinol., 13: 325-338.

- Zulu, V.C.; Sawamukai, Y.; Nakada, K., Kida, K. and Moriyoshi, M. (2002): Relationship among insulin-like growth factor-I, blood metabolites and postpartum ovarian function in dairy cows. J. Vet. Med. Sci., 64(10): 879-885.

تأثثر علاج الطفيليات على الكفاءة التناسلية للأبقار عديمة الثياع

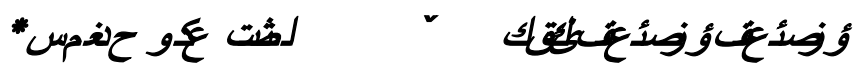

قسم التوليد والتناسل والتلقيح الاصطناعى كلية الطب البيطرى جامعة كفرالثيخ

* معهد بحوث صحة الحيوان بكفرالثيخ

تم استخدام عـد 35 بقـرة عديمـة الثـياع مصـابة بالطفيليـات الداخليـة لمعرفـة تأثير عـلاج الطفيليات على الكفاءة التناسلية للأبقار ـ تم فحص هذه الأبقار عن طريق المستقيم لمعرفة نثـاط المبيض وتكرر الفحص كل أسبوع لمعرفة التغيرات فى نشاط المبيض. تم تجميع عينات البراز من هذه 
الحيوانات وتم فحصها لتحديد أنواع وعدد بويضات الطفيليات الموجودة وتم علاج هذه الحيوانات بالعلاج

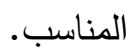

تم وضـع الحيوانـات تحت الملاحظة لمعرفة علامات الثياع وتم تلقيح الحيوانات فى مرحلة الثـياع. تم تجميع عينـات دم لتحديد مستوى البروجسترون والاستروجين وكذلك عامل النـو شبيه بالأنسولين IGFI وبعض مكونـات الـدم مثل الكالسيوم ، الفوسفور غير العضـوى ، والبـروتين. تم تشخيص الحمل بعد مرور 45 مرور من التلقيح. أظهرت نتائج هذه الدر اسة: 1- ان الطفيليـات السـائدة فـى حالــة عــدم الثــياع فـى الأبقـار هـى الفاشـيولا والبارامفتومم.

2- أن عـلاج الطفيليات يؤدى إلى زيـادة معنويـة فى تركيز كل من الكالسيوم ،

الفنفور غير العضوى ، الاستراديول ، البروجسترون و IGFI.

3- علاج الطفيليات يؤدى إلى تحسين الكفاءة التاسلية للأبقار عديمة الثياع كما ظهر فى زيـادة معدل الثياع ، زيـادة معدل الإخصـاب الأولى والكلى للأبقار

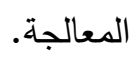

